PLANTS PEOPLE

POSSIBILITIES

Persian Gum. (Amygdalus leiocarpa, Boiss.)

Author(s): T. M. H.

Source: Bulletin of Miscellaneous Information (Royal Botanic Gardens, Kew), Vol. 1906, No. 4 (1906), pp. 109-110

Published by: Springer on behalf of Royal Botanic Gardens, Kew

Stable URL: http://www.jstor.org/stable/4113279

Accessed: 24-06-2016 22:28 UTC

Your use of the JSTOR archive indicates your acceptance of the Terms \& Conditions of Use, available at

http://about.jstor.org/terms

JSTOR is a not-for-profit service that helps scholars, researchers, and students discover, use, and build upon a wide range of content in a trusted digital archive. We use information technology and tools to increase productivity and facilitate new forms of scholarship. For more information about JSTOR, please contact support@jstor.org.

Royal Botanic Gardens, Kew, Springer are collaborating with JSTOR to digitize, preserve and extend access to Bulletin of Miscellaneous Information (Royal Botanic Gardens, Kew) 
Frutex nanus, ramosus, cortice cinereo. Folia opposita, fasciculata, 1-5 mm. longa, 0.5-1 mm. lata, lineari-trigona vel subteretia. Capitula terminalia; solitaria, 1-1.5 cm. longa, 6-8 $\mathrm{mm}$. diam., 5-9 flora. Involucri squamae subquinqueseriatae, interiores $1 \mathrm{~cm}$. longae, 2-2.5 mm. latae, lineari-oblongae, obtusae, exteriores gradatim minores, apice dorso gibboso-clentatae, virides, membranaceo-marginatae, subnitidae. Corolla $8 \mathrm{~mm}$. longa, tubulosa, basi contracta, apice 5-dentata, glabra; dentes $2 \mathrm{~mm}$. longae, lineari-oblongae, acutae, Ovarium pilis longis albis appressis dense vestitum. Pappi setae numerosissimae, lutescentes, exteriores breviores.

Cape Colony. Middelburg Division, $1100 \mathrm{~m}$., Gilfillan in Herb. Galpin, 5527.

\section{XIX.-PERSIAN GUM.}

\section{(Amygdalus leiocarpa, Boiss.)}

From time to time consignments of gum of dissimilar character appear in the commerce of this country as Gum Arabic, not the least interesting being the subject of this note. Little appears to have been written regarding this product however, but the following details gathered from the Pharmaceutical Journal, March 29th, 1890 , p. 793, may be quoted, not only as throwing light upon the subject, but also as an illustration : of the difficulty frequently experienced in determining the geographical as well as the botanical sources of a trade product. Quoting as his authority Professor E. Sickenberger, the writer of the note referred to says that it appears that quantities of this gum " are sent from Bushire, either "to a small port on the west coast of the Red Sea or to Jedda, in " order that it may be substituted for Kordofan gum. It is thence "conveyed to Assouan and packed in old Kordofan packages and "sold as genuine gum. Owing to its pale colour and the absence "of any suspicion that the gum from Assouan could be other than "good Gum Arabic, a considerable amount has been sold. The gum, "however, is described as not soluble in water, but only swelling " up in it, and as being less brittle than Kordofan gum. Professor "Sickenberger suggests that this Persian gum may be the produce " of Prunus bokhariensis, Royle, and Prunus Puddum, Roxb.

"The specimens of Persian gum that have appeared in the London

" market resemble East Indian or Senegal gum of good colour "lather than the white minutely cracked Kordofan gum."

With regard to the suggestion that this gum may possibly be derived from $P$. bokhariensis and $P$. Puddum, it may be well to state here that the Herbarium contains no specimens of the first mentioned species, and as far as can be ascertained there is no published description of it. In Hooker's Flora of British India, Vol. II., p. 315 , it is placed under $P$. communis, Huds., var. insititia, with the following note :- "I have seen no specimens " of Royle's P.: aloocha and bokhariensis, but have no reason to "doubt that they are referable to this." 
In response to an application made to the India Office, samples of the gums of $P$. Puddum and P. communis were collected in the Punjab and forwarded to Kew in July, 1890. These bear little resemblance to the Persian gum, though they agree with it in being insoluble in water.

The Museum contains three samples of Persian gum, all apparently identical. The oldest sample was received as "Wild Almond Gum" so long ago as August, 1854. Another sample formed part of 25 bags of "Persian Gum Arabic" imported from Bagdad and included in the London Drug Sales of June 9th, 1893. The third sample was collected by Dr. 0 . Stapf in 1885, who says of it:- "I may add that I saw a kind of cerasin (gummi nostras) "being sold in the bazaars at Shiraz for medicinal purposes. It "was called Ketirah-I-Arjen and stated to be derived from the "Arjen shrub (Amygdalus leiocarpa, Boiss.). Later I myself " collected it from this species on Kuk Chah Sia, north of Shiraz, " where it was plentiful on the ground underneath a few shrubs "and also on the stems. A sample of it is in the Museum. It "looks externally very like Gum Arabic. The same kind of gum " is also sold at Kirman under the name of 'Djäbd i Ardjän,' " whilst it is replaced by the gum of a plum ('Samgh-i-âlutschäh') "and of a cherry ("Samgh İ gîâs') in Ispahan." (See Andreas und Stolze in Peterm. Geogr. Mitth. Erganz., B. XVII., II., p. 15.)

From the notes and material obtained by Dr. Stapf it is evident that some if not the greater part of the Persian Gum of commerce is derived from Amygdalus leiocarpa, Boiss.

In the Diplomatic and Consular Report on the trade of Bushire for the year 1905 it appears that there is an increasing export of gum from that port, as the following figures show :-

\begin{tabular}{cc|c|c|c|c}
\hline \multirow{2}{*}{} & 1903. & 1904. & 1905. & Increase. \\
\hline & & Value. & Value. & Value. & \\
Gum $\ldots$ & $\ldots$ & $£ 38,046$ & $£ 64,869$ & $£ 70,949$ & $£ 6,080$ \\
\hline
\end{tabular}

J. M. H.

\section{XX.-PERPETUATION OF "POTATO DISEASE" AND POTATO "LEAF-CURL" BY MEANS OF HYBERNATING MYCELIUM.}

The sudden and simultaneous appearance of "Potato-disease," caused by Phytophthora infestans, De Bary, over widely extended areas in Britain and other countries has hitherto been attributed to the rapid production and diffusion of spores during a period when special meteorological conditions favoured the rapid development of the fungus. 